\title{
Software Service
}

National Cancer Institute

\section{Source}

National Cancer Institute. Software Service. NCI Thesaurus. Code C80736.

A software system providing a public need. 